\title{
ROZMOWY
}

Ryszard Zalski

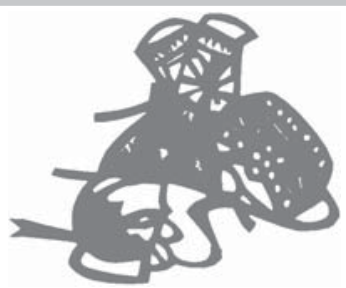

\section{OPINIE BO YANGA O TAJWANIE I CHINACH KONTYNENTALNYCH ORAZ O STANACH ZJEDNOCZONYCH I O WSPÓŁCZESNYM ŚWIECIE}

\section{Nota biograficzna}

Bo Yang (czasem pisany też jako Po Yang) jest jednym z najbardziej znanych współczesnych intelektualistów chińskich i niestrudzonym analitykiem „duszy chińskiej”, jej glorii i mrocznych zakamarków. Postać wielka i tragiczna zarazem. Człowiek, który - po latach prześladowań i więzień - dopiero u schyłku życia może cieszyć się zasłużoną sławą, dostatkiem i powszechnym szacunkiem. Zdobył uznanie przede wszystkim jako eseista pisujący o dziejach i kulturze chińskiej, chociaż jest także autorem ciekawych prac historycznych, m.in. dwutomowego Zarysu historii Chińczyków (Zhongguoren shi gang) od czasów legendarnych i popularnego przekładu z języka klasycznego na współczesny obszernych fragmentów wielkiego dzieła historycznego: Wszystko ukazującego zwierciadła ku pomocy w rządzeniu (Zizhi tongjian) Sima Guanga (1019-1086). Jest też poetą, krytykiem literackim i bojownikiem walczącym o prawa człowieka na Tajwanie. „The New York Times” nazwał go, jako propagatora wolnej myśli i racjonalizmu - „chińskim Wolterem”.

Urodził się w 1920 r. w średnio zamożnej rodzinie, w Kaifengu, jednej z dawnych stolic cesarstwa (był nią w epoce Północnej Dynastii Sung, 960-1127), a współcześnie dużym miastem prowincji Henan. Jego matka zmarła, kiedy był jeszcze niemowlęciem. Wychowywała go rodzina matki (w Kaifengu) i ojca (na prowincji), ale zaznał wszystkich goryczy sieroctwa, gdyż ojciec był w ustawicznych rozjazdach. Kierowany zapałem do nauki, wbrew woli ojca, uciekł od rodziny i zdał trudny egzamin na studia w liceum, najlepszym w Kaifengu (liceum było wtedy 
uznawane za bardzo elitarną i prestiżową „szkołę wyższą”). Odtąd sam przebijał się przez życie. Po napaści Japonii na Chiny i wybuchu wojny w 1937 r., razem z tysiącami uciekinierów-patriotów, ewakuował się - wraz z kolejnymi etapami klęsk - aż do Sichuanu, gdzie ostatecznie schronił się rząd Republiki Chińskiej.

Tam w 1946 r. ukończył Uniwersytet Północnego Wschodu (Dongbei Daxue), ewakuowany z Mandżurii zajętej przez Japończyków w 1931 r., a następnie wyjechał do wyzwolonej Mandżurii, gdzie miał wielu znajomych ze studiów. Tak znalazł się w ogniu wojny domowej toczonej między siłami Partii Narodowej - Guomindangu (Kuomintangy, KMT) i komunistów, gdyż w Mandżurii zaczęła się ona najwcześniej, już w 1946 r. W 1949 r., wraz z tysiącami innych uciekinierów przed komunistami, znalazł się na Tajwanie.

Nie podzielał wielu poglądów rządzącej KMT i był krytycznie nastawiony wobec totalitarnej dyktatury tej partii ustanowionej na wyspie, za co spotykały go rozmaite represje. W 1968 r., bez wyroku sądu, został osadzony w ciężkim więzieniu politycznym na Wyspie Huoshao. Groziła mu wtedy nawet kara śmierci. Warto dodać, że uwięziono go za przetłumaczenie komiksu Popeye'a, w którym pewien marynarz rozmawia ze swoim synem. Tekst ten władze uznały bowiem za aluzyjną krytykę rządów prezydenta Chiang Kaj-sheka (Jiang Jieshi, Czang Kai-szek) oraz jego syna Chiang Ching-kuo. Tak stał się jedną z tysięcy ofiar trwającego prawie cztery dekady tzw. „białego terroru” KMT (tak nazywanego na Tajwanie, by odróżnić go od „czerwonego” na kontynencie). Uwolniono go, dzięki wielu naciskom nie tylko z kraju, ale i z zagranicy (przede wszystkim za staraniem Amnesty International oraz władz USA), dopiero w 1977 r., po 9 latach i 26 dniach. Jednak nawet i później zatruwano mu życie i utrudniano pracę.

Dzień swego uwięzienia (7 marca) uznał on później jako swe „powtórne narodziny", gdyż otworzyło to nową kartę jego życia. Dopiero na przełomie lat 80 . i 90., wraz z demokratyzacją życia politycznego na Tajwanie, ze stopniowym demontażem dyktatury KMT oraz zniesieniem cenzury - zyskał możliwości swobodnego życia i publikowania.

Według stanu na koniec 1998 r. na jego dorobek składają się 53 własne książki, 7 tomów zredagowanych przez niego oraz wiele zbiorów jego esejów i studiów, krytyk, reportaży, artykułów wcześniej publikowanych w prasie, biografii i thumaczeń z języków obcych. Jego książkę Obca kraina (z listopada 1977 r., znaną także jako The Alien Realm) sprzedano na Tajwanie w ponad milionie egzemplarzy.

Chiny kontynentalne odwiedził dopiero po zniesieniu na Tajwanie w 1987 r. stanu wyjątkowego, kiedy zezwolono na takie podróże. Po powrocie na wyspę napisał książkę Dom (1989 r.), w której występuje jako przedstawiciel pierwszej generacji przybyszów na Tajwan z 1949 r., którzy jednak, tak jak ich dzieci, traktują już wyspę jako „swój dom”.

Jako działacz na rzecz praw człowieka, w 1995 r. założył Fundację ds. Kształcenia o Prawach Człowieka. Jego ogromne zaangażowanie w transformację kul- 
turową, pracę literacką i obronę praw człowieka zostało uhonorowane przyznaniem mu w 1999 r. Humanity Award. Można dodać, że po zwycięstwie opozycji w wyborach prezydenckich, w 2000 r., przy zaangażowaniu samego Bo Yanga, więzienie na Wyspie Huoshao przekształcono w muzeum zbrodni dyktatury KMT i pomnik obrony praw człowieka. Później ten więzienny epizod ze swojej biografii skomentował następująco: Tylko ten naprawdę będzie cenit wolność, kto ja stracił, $i$ ten zrozumie strach $i$ cenę życia, kto kiedykolwiek staną twarza w twarz ze śmiercią.

Jego najgłośniejszym dziełem, wzbudzającym na Tajwanie, w Chinach kontynentalnych, a także we wszystkich centrach diaspory chińskiej, ogromne emocje i kontrowersje, był zbiór esejów oraz wywiadów: Wstrętni Chińczycy (Chouloude Zhongguoren, opublikowany w 1985 r.). Wydano go w języku angielskim jako: The ugly Chinaman and the crisis of Chinese culture. W ciagu trzech lat na samym Tajwanie ukazało się kilkanaście wznowień tej pracy, a jego polemiści opublikowali na jej temat niezliczoną liczbę artykułów i kilka książek. Podejmuje w tej pracy rozważania dotyczące ,narodowych wad” Chińczyków, jak też kultury i mentalności konfucjańskiej. Wielekroć powtarza tam bardzo przykrą dla Chińczyków tezę, iż daleko ustępują oni Japończykom i bez zasadniczych przemian w mentalności narodowej Chiny nigdy nie dorównają Japonii. Było to tym bardziej bolesne, iż rany agresji japońskiej na Chiny pozostają wciąż niezagojone, a wielu Chińczyków patrzyło z pewną pogardą na swych sąsiadów ze wschodu, jako dawnych „,barbarzyńców", którzy z Chin zapożyczali rudymenty swej cywilizacji.

Współczesnych Chińczyków przedstawiał wprawdzie jako spadkobierców jednej z najstarszych i najwspanialszych kultur świata, ale stawiał też trudne pytania: jak to możliwe, by naród o tak wspaniałym dziedzictwie tak dalece się zdegenerował w erze nowożytnej? Wady Chińczyków są, jego zdaniem, jak choroba przekazywana z pokolenia na pokolenie. Aby oddać charakter społeczeństwa chińskiego użył przykrych metafor: „,cebrzyk z marynowanymi warzywami” (pickle jar) i ,beczułka z pastą sojową" (soya paste vat). W oryginale odwołuje się on do naczyń ceramicznych, nie zaś drewnianych, w Chinach nieznanych, lecz dla tamtejszych brak polskich określeń. W tych naczyniach wszystko, co tam wpada, kisi się i maceruje, w ciemnej, śmierdzącej cieczy.

Za początek schyłku wspaniałej kultury i myśli chińskiej uznaje pojawienie się konfucjanizmu. Światopogląd przez doktrynę tę wpajany, zgodnie z opinią Bo Yanga, nie pozwalał uczniowi wybić się ponad swego mistrza, zmuszając go do pozostania w cieniu mentora, co hamowało wszelki rozwój i pojawianie się nowych idei. Taki sam skutek miało respektowanie konfucjańskiego wymogu czci i posłuszeństwa rodzicom, oraz ścisłego zachowywania ustalonych przez nich porządków - po ich śmierci. Bo Yang przeciwstawił się więc zdobywającym wtedy popularność koncepcjom, które objaśniały zadziwiający rozwój gospodarczy krajów Azji Wschodniej wpływami tradycji konfucjańskich. 
Wytykał również swym rodakom hałaśliwość i brud, piętnował brak szczerości i ogłady, a także chełpliwość i kłótliwość, nieustanne walki między grupami i frakcjami, co uniemożliwia solidarne działania narodowe. Zarzucał im ponadto ograniczone horyzonty umysłowe i tendencje psychotyczne. Według autora tradycje feudalne w stosunkach społecznych, wpajanie ortodoksyjnego konfucjanizmu i system egzaminów publicznych do służby cywilnej (zrodzony jeszcze w starożytności), a będący podstawą „władzy mandarynów”, przyczyniały się do stagnacji w kulturze, co z kolei podtrzymywało ignorancję i arogancję jako cechy narodowe. Instytucja rodziny pod wpływem konfucjanizmu ulegała skostnieniu i niszczyła wszelkie przejawy indywidualnej inicjatywy oraz niezależnego rozumowania. Potępiano szczere wyrażanie emocji przez jednostki wpajając obłudę „dla podtrzymywania jedności rodziny", co deformowało współdziałanie i stosunki w społeczeństwie.

Jak pisał: Wszelkiego rodzaju przejawy chaosu pojawiaty się w wyniku występowania owych dwóch, pozornie przeciwstawnych cech, jakimi byty arogancja i uległość. W efekcie ludzie nie mogli pielęgnować własnej godności lub też szanować godności innych.

Antidotum na te bolączki widział w przyswojeniu przez Chińczyków niektórych ze zdobyczy Zachodu, szczególnie z kultury anglosaskiej. Za kluczowe uznał praworządność i trójpodział władz. Do czasu ich przyswojenia życie publiczne w Chinach, jego zdaniem, będzie zdegenerowane. Jak pisał, właśnie dlatego na Zachodzie demokracja jest częścią życia codziennego, a w Chinach istnieć może co najwyżej na pokaz. Koncepcje przedstawione w tej książce po raz pierwszy rozwinął i zaczął propagować w trakcie cyklu wykładów wygłaszanych przez kilka tygodni w 1984 r. w USA.

Tezy te budziły żywe i emocjonalne polemiki oraz krytyki, ale książka przyniosła zarazem autorowi ogromny rozgłos w świecie chińskim i zapewniła mu szczególny status: autorytetu narodowego, który odważa się szargać wszystkie świętości. Mimo podeszłego wieku uczestniczy on nadal w życiu politycznym i społecznym Tajwanu, a najwyżsi dostojnicy państwowi chętnie pokazują się w jego towarzystwie.

Jego żona, Chang Shiang Hua (Zhang Xianghua), jest znaną poetką. Wykładała literaturę chińską na miejscowych uniwersytetach. Otrzymała wiele międzynarodowych nagród poetyckich, a jej wiersze tłumaczono na wiele języków (w Polsce ukazał się jej tomik Wiersze, przekł. Rafał Gajewski, Oficyna Literacka, Kraków 2000). Była też działaczką Amnesty International na Tajwanie.

Opracowat Ryszard Zalski, przy udziale Krzysztofa Gawlikowskiego. 


\section{Rozmowa z Bo Yangiem}

Wywiad dla „Azji-Pacyfiku” został przeprowadzony w maju 2003 r. w mieszkaniu Pana Bo Yanga na przedmieściach Tajpei, przez R. Zalskiego. Rozmowę tłumaczyła na język angielski jego żona. Bo Yang, uznawszy tę rozmowę za ciekawą również dla czytelnika chińskiego, opublikował ją na swojej kolumnie w miesięczniku ukazującym się w Hongkongu.

\section{- Jakie były Pańskie wrażenia z odwiedzin USA?}

Bardzo, ale to bardzo lubię Stany Zjednoczone. Ogromnie je cenię. To prawdziwie demokratyczny kraj. Nigdy nie mieliśmy takiego systemu w Chinach.

- Czy ta uwaga dotyczy również Tajwanu?

Zazwyczaj, kiedy mówimy o Chinach, mamy głównie na myśli Chiny kontynentalne. Demokracja jest z pewnością celem walki wszystkich Chińczyków.

- Czy zechciałby Pan to nieco rozwinąć?

Celem ich jest przekształcenie kraju w wolny i demokratyczny.

- Czy odnosi się to do Chin kontynentalnych i do Tajwanu?

Tak, do obydwu.

- Czy Pana zdaniem, zarówno Chińska Republika Ludowa, jak i Republika Chińska na Tajwanie (ROC), powinny naśladować wzory ustrojowe Stanów Zjednoczonych?

Tak, powinny. Powinny do tego dążyć. Już podejmują wysiłki w tym kierunku i tego pragną. Tylko w ten sposób mogą też zdobyć szacunek w świecie.

- Czy to jest właśnie podstawą szacunku dla nich również na Tajwanie?

Niestety, nie wszyscy Tajwańczycy to doceniają. Ja osobiście bardzo szanuję Stany Zjednoczone za ich demokratyczne zasady. W sferze politycznej kluczowe było uformowanie trójpodziału władz. My w Chinach nigdy nie pragnęliśmy tego nawet. Ponadto doceniam walkę Amerykanów o moje uwolnienie z więzienia.

- Czy odegrała ona zasadniczą rolę?

Takie jest moje osobiste przekonanie.

\section{- Czy jest coś, co rozczarowuje Pana w USA?}

Żaden kraj nie jest doskonały. Smutne jest dziedzictwo rasizmu. Np. Murzynom i Indianom w Stanach Zjednoczonych wciąż nie okazuje się należytego szacunku.

- Jakie były Pańskie odczucia, kiedy w latach 70. Tajwan został usunięty z ONZ, a miejsce Chin zajęla delegacja z Pekinu?

Zapewnianie własnemu krajowi korzyści jest zazwyczaj sprawą priorytetową dla każdego rządu. Nie powinno się tylko poświęcać życiowych interesów kra- 
ju-przyjaciela dla własnego dobra. Każdy silny kraj ma jednak prawo wybierać - i zmieniać swoich przyjaciół.

- Czy więc nie obwinia Pan Amerykanów za to, co się stało?

Trudno pochwalać zdradę między przyjaciółmi. Nie możemy jednak oczekiwać od przyjaciela, żeby robił coś, czego sami byśmy nie zrobili dla naszego przyjaciela.

- W jakim sensie?

Na przykład, gdybyśmy to my znajdowali się wtedy na miejscu przywódców USA, zapewne tak samo byśmy postąpili i dokonali takiego właśnie wyboru.

- Dwa tygodnie temu rozmawialem $\mathrm{z}$ jednym $\mathrm{z}$ czolowych tutejszych dyplomatów, który reprezentowal Tajwan w USA. Powiedzial mi mniej więcej to samo. Stwierdzil mianowicie że Tajwan i USA utrzymywały przez długi okres bardzo przyjacielskie stosunki, a Waszyngton wielokrotnie wspomagal Tajwan. Jednak wladze tajwańskie zdawały sobie sprawę, że zmiana opcji Waszyngtonu jest nieunikniona i USA postąpią w taki właśnie sposób.

Nie w pełni rozumiem Pański komentarz. Jeśli mamy do czynienia z długą i wieloletnią przyjaźnią, a pewnego dnia jedna strona opuszcza drugą, to cóż to oznacza? Jedynie tyle, że przyjaźń pewnego dnia się kończy. Często w grę wchodzą też jakieś interesy.

- Stwierdzil Pan, że Tajwańczycy nie mogą oczekiwać, by Amerykanie czynili dla nich więcej, niż oni sami chcieliby uczynić dla swoich przyjaciól. To chyba bardzo bliskie temu, co powiedzial ów dyplomata?

Nie do końca. Sprawa uznania władz w Pekinie nie ma nic wspólnego z wieloletnią przyjaźnią wobec Tajwanu. Znaliśmy się długi czas, ale Amerykanie mają swoje interesy i z pewnością nie będą chcieli za nas walczyć. Tajwan umocnił się również bardzo. Mimo nowej przyjaźni z silniejszym partnerem [tj. ChRL], Waszyngton nie zerwał jednak przyjaznych stosunków z nami.

- Tak więc sądzi Pan, że mimo wszystko Waszyngton wciąż utrzymuje jednak przyjazne stosunki z Tajwanem?

Bez ochrony udzielanej Tajwanowi przez USA i ich przyjaźni, bylibyśmy całkowicie straceni. Jeśli Waszyngton wycofałby swe poparcie dla Tajwanu, musielibyśmy po prostu poddać się Chinom kontynentalnym.

- Jak ocenia Pan obecne stosunki przyjaźni Pekinu z Waszyngtonem i Tajpei z Waszyngtonem?

Nie w pełni zgadzam się z używaniem terminu „przyjaźń” w tym kontekście. Trzeba pamiętać, że nie istnieje ona $\mathrm{w}$ istocie między państwami. Jak mówili Brytyjczycy, państwa nie mają ani wiecznych przyjaciół, ani wiecznych wrogów, ale zawsze mają swoje interesy. Doceniamy życzliwość Waszyngtonu. Jeżeli stracilibyśmy takiego przyjaciela, byłoby nam bardzo przykro i miałoby to - jak mówiłem - poważne konsekwencje. 
Stany Zjednoczone mogły wysłać ambasadora do Pekinu w ramach nawiązanych oficjalnie stosunków dyplomatycznych. Nie mogą jednak porzucić całkowicie Tajwanu, gdyż to bardzo nadwyrężyłoby ich prestiż w oczach innych ich przyjaciół w Azji.

- Co sądzi Pan o wpływie USA na spoleczeństwo tajwańskie? Wielu badaczy wyjeżdża do USA pisać doktoraty, czy robić tam karierę. Później jednak zazwyczaj wracają do kraju. Wiele innych osób wyjeżdża na studia i staże. Czy daje to Tajwanowi korzyści również $w$ innych sferach niż sprawy polityczne?

Przede wszystkim umacnia to nasze bezpieczeństwo i to w wielu aspektach. Nasze społeczeństwo jest dzisiaj dosyć stabilne. Staliśmy się częścią układu ekonomicznego z USA. Przyswajamy sobie coraz bardziej kulturę amerykańską. Nawet w sferze emocjonalnej Tajwańczycy stali się dzisiaj znacznie ściślej związani z USA, niż Chińczycy z kontynentu.

- Jednym z moich zdziwień po przyjeździe na Tajwan był stopień zachowania „natury chińskiej”. Oczekiwałem, że społeczeństwo tutejsze będzie w znacznie większej mierze zamerykanizowane. W swojej książce Wstrętni Chińczycy stwierdził Pan, że Chińczycy podziwiają Stany Zjednoczone i marzą o wyjeździe oraz pracy tam. Odnoszę jednak wrażenie, że Tajwańczycy są bardzo przywiązani do swojego kraju i zazwyczaj wracają po pobycie w USA.

Zamerykanizowanie Chińczyków nie jest sprawą łatwą. Mamy za sobą tradycję pięciu tysięcy lat. Nawet jeśli ktoś oczekuje zmiany naszej kultury, nie może następować to szybko. Podlegała ona jednak bardzo już znacznym zmianom pod wpływem kultury Zachodu. Jako przykład mogę podać obecność chrześcijaństwa i pojawienie się kościołów. Dla was to może normalne, ale dla nas ich pojawienie tutaj - to ogromna zmiana. Także konstrukcja współczesnych budynków jest typu zachodniego, podobnie całkowicie zachodnie jest umeblowanie większości domów.

- Jak widzę sami Państwo macie dom urządzony na sposób zachodni.

Właśnie. Przez tysiące lat praktycznie nie mieliśmy gazet. Kiedy byłem małym chłopcem, praktycznie nie widywałem gazet. Obecnie zaś jest ich tak dużo! Uczymy się więc kultury Zachodu. Jeśli w dawnych czasach ktoś wymówił imię cesarza, groziło mu ścięcie głowy. Jeszcze 150 lat temu zakazywano Chińczykom uczenia cudzoziemców swego języka, a cudzoziemcom uczenie się chińskiego. Kiedy wówczas pastorzy przybywali do Chin, musieli przygotować sobie zawczasu truciznę, gdyby bowiem władze wykryły, że osoba taka zna nasz język, najlepiej byłoby dla nich od razu popełnić samobójstwo. Obecnie sami propagujemy naukę chińskiego wśród cudzoziemców. Lubimy nawet spotykać się z cudzoziemcami i zawierać z nimi przyjaźnie. Obecnie możemy także wymawiać imię prezydenta i pozdrawiać go przy okazji publicznych spotkań z nim, jakich w cesarstwie nigdy nie było. Jeszcze kilka dekad temu przy okazji takich mityngów musieliśmy stać 
na baczność i okazywać czołobitność władzom. Teraz możemy swobodnie piętnować i krytykować prezydenta i premiera. Jeszcze za czasów prezydenta Czang Kaj-szeka było to zupełnie niemożliwe.

- Powinien Pan być chyba zadowolony z zachodzących na Tajwanie przemian. W książce Wstrętni Chińczycy wyrażał Pan nadzieję, że kultura zachodnia pomoże Pana rodakom przezwyciężyć wady ich własnej kultury.

Tak, w istocie jestem zadowolony. Naszej kulturze brakowało wolności, poszanowania godności, wzajemnej pomocy w skali społecznej, a nie tylko rodzinnej, jak też szczerości i tolerancji. W kulturze europejskiej oraz amerykańskiej takie elementy są utrwalone. Ustrój demokratyczny wymaga również racjonalnego myślenia, jakiego brakowało u nas. Pragniemy stworzenia nowego społeczeństwa, odmiennego od dawnych form.

- Kiedy opublikowal Pan tę książkę, wielu intelektualistów chińskich ostro ją krytykowało. Czy stosunek do Pańskich tez zmienial się jakoś z upływem czasu? Czy teraz Pańskie poglądy spotykają się z większym zrozumieniem?

Myślę, że teraz dość powszechnie ludzie się ze mną zgadzają, włączając w to przyjaciół z kontynentu. Dla mnie czytelnicy, także moi odbiorcy z ChRL, są bardzo ważni i powinni się chyba ze mną zgadzać, bo chodzi mi przecież o szacunek dla każdego człowieka i poprawę obecnego stanu. W zeszłym roku opublikowałem nawet książkę poświęconą temu problemowi: Powinniśmy żyć w godności. Podróżowałem po ChRL, odwiedziłem 6 dużych miast i miałem wiele spotkań. Zazwyczaj mówiono mi, że przyswajanie sobie kultury Zachodu wydaje się być lekarstwem na rozmaite bolączki Chin, co ja również zalecałem.

- Na Zachodzie wiele osób fascynuje się kulturą i dorobkiem Chin. Czy Chińczycy mogą rzeczywiście, Pana zdaniem, zaoferować coś pożytecznego Zachodowi?

Ludzie Zachodu nastawieni są przede wszystkim na stały postęp i rozwój techniki. Od Chińczyków mogą się chyba nauczyć, jak odpoczywać i cieszyć się życiem. Oto metaforyczna opowiastka o bogatym Amerykaninie i biednym Chińczyku, którzy łowią ryby. Amerykanin mówi: mogę teraz siedzieć i odpoczywać, bo przez dwa lata wydajnie pracowałem i dzięki mnie firma zarobiła dużo pieniędzy. Chińczyk mówi: w pewnym sensie jesteśmy podobni, ja jednak nie muszę wcale tak ciężko pracować ani zarabiać pieniędzy i dlatego właśnie tu siedzę. Oto jedna $\mathrm{z}$ różnic mentalnych. Amerykanie pracują tak dużo, że nie umieją nawet odpoczywać, my zaś potrafimy cieszyć się życiem, nawet mając o wiele mniej.

Obecnie obawiam się, że Amerykanie mogą przegrać wojnę w Iraku. Jednak jeszcze bardziej boję się ich wygranej. Staliby się wtedy jedynym - bezdyskusyjnie - supermocarstwem świata. W Chinach mamy stare powiedzenie: ,jeśli teraz nie masz wroga, twój kraj wcześniej czy później spotka się jednak z zagrożeniem". Kiedy państwo staje się nazbyt silne, osiąga szczyt swych możliwości, w przyszłości czeka go schyłek, a nawet łatwo może upaść. 
Opowiem krótką historyjkę, z czasów II wojny światowej. Działo się to w Birmie, na cmentarzu. Znajdował się tam wielki kamień. Stał przy nim pewien muł. Zwierzę to znane było z tego, że kopało żołnierzy. Z czasem tak się rozzuchwaliło, że zaczęło kopać nawet generałów. I nikt nie był w stanie go poskromić. Aż pewnego dnia, kopiąc tak wszystko, zwierzę kopnęło minę. Dla Napoleona taką miną była Moskwa. Dawniej jeszcze, dla Hiszpanii - stała się nią flota brytyjska. Podobnie może być ze Stanami Zjednoczonymi. W chwili obecnej nie wiemy tylko, co będzie ich „miną”. Mogą nią stać się zarówno Chiny, jak Rosja, albo nawet przeciwnik pozornie jeszcze mniejszy. Chodzi mi o to, że brak wroga, demobilizujący państwo i stymulujący jego arogancję, w dłuższej perspektywie, może prowadzić do zagłady supermocarstwa.

\section{- Co wydaje się dzisiaj najważniejsze dla Chińczyków?}

Paradoksalnie najważniejsze, bez wątpienia, jest wciąż jedzenie i zaspakajanie głodu oraz swoich fantazji w tej dziedzinie. Nawet gdy głód, jako klęska, w zasadzie został już zlikwidowany, także na kontynencie, Chińczycy pragną przede wszystkim napełniać swoje żołądki, jeśli można - smacznie. Ludzie na Zachodzie stale dążą do sukcesów i postępu, zawsze chcą mieć i osiągać więcej. W Chinach mamy natomiast powiedzenie: ,jeśli chcesz być zadowolony, doceniaj to, co masz". Na Zachodzie ludzie bez przerwy starają się pomnożyć i zwiększyć swoje dotychczasowe osiągnięcia. Chińczycy dużo łatwiej cieszą się tym, co już mają, a w rezultacie są za mało ,agresywni”. Wydaje się, że dlatego właśnie Zachód interesuje się Wschodem: brakuje mu bowiem wschodniego spokoju. cie?

- Skąd wzięla się, Pana zdaniem, dominacja Stanów Zjednoczonych w świe-

Amerykanie wywodzą się z Europy, tak więc kultura ich jest starsza niż 200 -300 lat, o których zazwyczaj się mówi. Emigranci tam przybywający mieli własne religie oraz kulturę. Na początku sprzeciwiali się Brytyjczykom oraz dominacji jednej religii, zwłaszcza katolickiej. Rok po założeniu USA, dokładnie w czasie, kiedy Amerykanie powstali przeciw władzy Brytyjczyków, w okresie rządów cesarza Qian Longa, trwała rebelia w prowincji Xinjiang. Powstanie to ostatecznie stłumiono, a niektórych z rebeliantów oddano na śmierć w torturach. Rok po tym wydarzeniu, opublikowano dzieło, w którym użyto imienia cesarza [co było złamaniem pilnie przestrzeganego tabu]. W ramach kary wykopano, m.in. i zbezczeszczono zwłoki autora. Władze cesarskie w Chinach uciekały się często do przemocy. W tym okresie w USA wprowadzano trójpodział władzy, wcześniej wymyślony w Europie. Chińczycy mieli odkryć jego walory dopiero 200 lat później. Czy można porównywać Lincolna ze wspomnianym cesarzem, uchodzącym za „wielkiego"? Tak więc kultura amerykańska wcale nie jest niższa od chińskiej, jak czasem mówią tradycjonaliści. $Z$ obu stron potrzebny jest szacunek dla partnera.

\section{- Dziękuję za rozmowę.}

